\title{
Ti 合金溶接金属の凝固割れに関する検討*
}

一 Ti 合金の溶接に関する研究（第 2 報）一

井上裕滋**，小川忠雄**

\author{
Solidification Cracking in the Wel Metal of Titanium Alloys* \\ -Study on Welding of Titanium Alloys (Report 2)- \\ by Hiroshige Inoue** and Tadao Ogawa**
}

\begin{abstract}
Susceptibility to weld solidification cracking of three kinds of Ti-alloys was investigated by TransVarestraint test. Weld crackings did not occur in Ti-6Al-4V at all, but significantly occurred in Ti-6Al$6 \mathrm{~V}-2 \mathrm{Sn}$ and Ti-15V-3Al-3Cr-3Sn. Ti-15V-3Al-3Cr-3Sn was actually the most susceptible to cracking. Through close examination of weld solidification microstructures by tin-quenching, conspicuous segregations of $\mathrm{V}, \mathrm{Cr}, \mathrm{Cu}$ and $\mathrm{Fe}$ were confirmed at dendritic grain boundaries during solidification in each alloy The diffusion rate of solute elements in Ti-6Al-6V-2Sn and Ti-15V-3Al-3Cr-3Sn was 1 order smaller than that in $\mathrm{Ti}-6 \mathrm{Al}-4 \mathrm{~V}$. Consequently, the amount of compositional microsegregation at dendritic boundaries in the former alloys was larger, because the effect of solid diffusion during solidification was smaller. In Ti-6Al-4V, these microsegregations were readily decreased and eliminated by the occurrence of solute diffusion at very early stage of weld cooling, while that in the other alloys remained till rather lower temperature to cause crackings due to liquid films of low-melting constituents.
\end{abstract}

Key Words: Titanium alloy, Weld, Solidification cracking, Hot cracking, Microstructure, Solidification, Segregation, Diffusion

\section{1. 緒 論}

$\mathrm{Ti}$ 合金は一般に耐凝固割れ性に優れている(1-3) と言わ れているが, 若干の合金系において疑固割れが報告1,2,4) されている。しかしながら，それらの割れ感受性および 発生機構について詳細に検討した報告は少ない。乙れ は, $\mathrm{Ti}$ 合金が bcc 構造である $\beta$ 相で単相疑固するため に凝固組織の現出が困難であり，凝盾挙動の検討が必ず しむ十分になされていないためである。

そとで，本研究では，代表的な $\alpha+\beta$ 系および $\beta$ 系 $T i$ 合金の凝固割れ感受性の比較，および割れ発生機 構 について，凝固，拡散挙動の観点から検討を行なった。

\section{2. 供試材料およひ実験方法}

本研究に用いた供試材料は， $\alpha+\beta$ 系の $\mathrm{Ti}-6 \mathrm{Al}-4 \mathrm{~V}$ および Ti-6 Al-6 V-2 Sn 合金, $\beta$ 系の Ti-15 V-3 Al-3 Cr-3 Sn 合金の三種類で, それらの化学組成を Table 1 に示す。なお板厚はいずれあ $6 \mathrm{~mm}$ である。

溶接金属の凝固割れ感受性の評価は，Fig. 1 に示す卜 ランスーバレストレイン試験によって行なった。試験片 寸法は， $100 \times 80 \times 6 \mathrm{mmt}$ とし，試験溶接は GTAW に よるメルトラン溶接で行ない, 溶接条件は $100 \mathrm{~A}-15 \mathrm{~V}$ $1.67 \mathrm{~mm} / \mathrm{sec}$ とした. 試験方法は, Fig. 1 のA点からC 点に向かって GTA 溶接を行い, 溶融池がB点に達っし た瞬間, 落下速度 $300 \mathrm{~mm} / \mathrm{sec}$ でョークを落下させて, 溶接金属に歪を付加し, 割れを発生させた。 また, 付加 ひずみ量は曲げブロックの曲率を変えることにより， $0.5 \%$ から $8.3 \%$ までの範国で 8 段階に変化させた。発生 した割れは，20〜50倍の実体顕微鏡で観察し，割れ長さ

\footnotetext{
・原稿受付 平成 2 年 5 月 31 日 昭和 63 年度秋季全国大会で発表

**正員 新日本製鐵㮫接合研究センター Member, Nippon Steel Corporation
}

Table 1 Chemical compositions of materials used $(w \mathrm{t} \%)$

\begin{tabular}{|l|c|c|c|c|c|c|c|c|c|c|c|}
\hline \multicolumn{1}{|c|}{ Alloy } & Al & $\mathrm{V}$ & $\mathrm{Sn}$ & $\mathrm{Cr}$ & $\mathrm{Cu}$ & $\mathrm{Fe}$ & $\mathrm{O}$ & $\mathrm{N}$ & $\mathrm{C}$ & $\mathrm{H}$ & $\mathrm{Ti}$ \\
\hline $\mathrm{Ti}-6 \mathrm{Al}-4 \mathrm{~V}$ & 6.46 & 4.22 & - & - & - & 0.22 & 0.12 & 0.01 & 0.01 & 0.0011 & Bal \\
\hline $\mathrm{Ti}-6 \mathrm{Al}-6 \mathrm{~V}-2 \mathrm{Sn}$ & 5.47 & 5.70 & 1.96 & - & 0.75 & 0.75 & 0.18 & 0.01 & 0.01 & 0.0019 & Bal \\
\hline $\mathrm{Ti}-15 \mathrm{~V}-3 \mathrm{Al}-2 \mathrm{Cr}-3 \mathrm{Sn}$ & 2.90 & 15.30 & 2.98 & 3.03 & - & 0.21 & 0.13 & 0.01 & 0.01 & 0.0078 & Bal \\
\hline
\end{tabular}

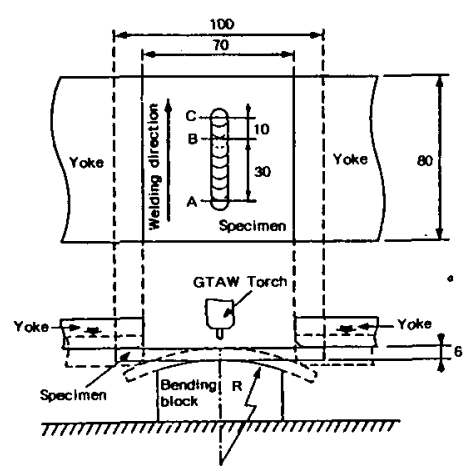

Fig. 1 Schematic appearance of the TransVarestraint apparatus

を測定した：

割れ破面上の元素分析はオージェ電子分光分析（以下 AES と記す）で行ない，測定条件は $5 \mathrm{kV}-1 \mu \mathrm{A}$ とした. 溶䝯元素の拉散速度の測定には，Ti 合金とステンス 鋼とを拡散接合し，接合界面近傍におりる接合界面に值 角方向の元素分布の測定值を用いて計算により求めた。 拡散接合には，Ti 合金として Table 1 の三合金の他に， 比較のために工業用純 $\mathrm{Ti}$ (JIS 1 種相当) を用い，ス テンレス鋼としては，極低 C の SUS 444（0.004 C-19 


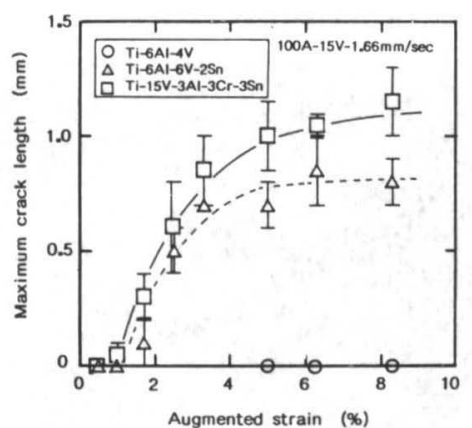

(a) Maximum crack length

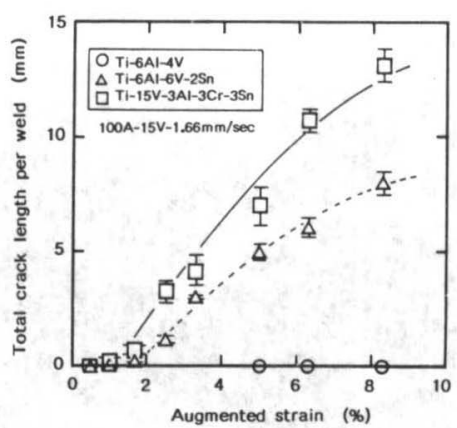

(b) Total crack length

Fig. 2 Evaluation of solidification crack susceptibility of Ti-alloys obtained by the TransVarestraint test

Cr）鋼を用いた。試験片は $10 \phi \times 20 \mathrm{mml}$ に旋盤加工 後, 接合面を\#600エメリ一紙によって研磨し, アセト ンで脱脂後, 接合試験を行なった。接合䨌囲気は $10^{-4}$ Torr の真空とし, 接合は $1.5 \mathrm{~N} / \mathrm{mm}^{2}$ の圧力制御にて行 なった，試験片の加熱は高周波誘導加熱で行ない，加熱 速度は $10 \mathrm{~K} / \mathrm{sec}$ で一定とし, 所定温度に到達後の経過時 間を接合時間とした。なお本夷験の接合温度は $1273 \mathrm{~K}$, $1298 \mathrm{~K}, 1323 \mathrm{~K}$ の三段階とし, 接合時間は $1800 \mathrm{sec}$ 一 定とした.

凝固組織の現出方法, 組織観察方法, 元素分布测定方 法は前報5) と同樣である.

\section{3. 実験結果およひ考察}

\section{1 各種 $\mathrm{Ti}$ 合金の溶接凝固割れ感受性}

Ti-6 Al-4 V, Ti-6 Al-6 V-2 Sn 及び Ti-15 V-3 Al-3 Cr-3 Sn の三合金について, 付加ひずみ量を変えてトラ ンスーバレストレイン試験を行ない, 測定した最大割れ長 さおよび総割れ長さを Fig. 2 に示す. Ti-6 Al-4 V 合金で は, 付加ひずみ量が增加しても割れは全く発生せず, 極 めて耐凝固割れ性が優れていることが判明した。一方， Ti-6 Al-6 V-2 Sn, Ti-15 V-3 Al-3 Cr-3 Sn 合金では付 加ひずみ量が $0.5 \%$ までは割れは発生しないが, それを 越えると割れが発生し, 付加ひずみ量の増加に伴って割 れ長さは増加している。 また, Ti-15 V-3 Al-3 Cr-3 Sn 合金の方が Ti-6 Al-6 V-2 Sn 合金より最大割れ長さお よび総割れ長さとも大きくなっている，さらに，付加ひ ずみ量が $5 \%$ 以上では両合金とむ最大割れ長さはほぼ一 定となっている, そこで, 割れ感受性を評価するため, 物理的意味の明確な割れの温度範囲を表わす凝固脆性温 度領域 (BTR) を求め, 比較を行なった。ここで, BTR は割れが進展する最低温度と液相線温度との差で表わし たむのであり, 付加ひずみ量が $5 \%$ の場合最大割れ長さ を, ビード中央部の温度分布の実測結果と組み合わせて 温度に換算して求めた. 測定の結果, BTR は Ti-6 Al$6 \mathrm{~V}-2 \mathrm{Sn}$ 合金では $157 \mathrm{~K}, \mathrm{Ti}-15 \mathrm{~V}-3 \mathrm{Al}-3 \mathrm{Cr}-3 \mathrm{Sn}$ 合 金では $220 \mathrm{~K}$ となり, Ti-15 V-3 Al-3 Cr-3 Sn 合金の 方が割れ感受性は BTR にして約 $60 \mathrm{~K}$ 高いととが判明 した。 また，これら $\mathrm{Ti}$ 合金の凝固割れ感受性は，一般 に凝固割れ感受性が高いと言われている $\mathrm{Ni}$ 基耐熱合 金6) とほぼ同程度である。

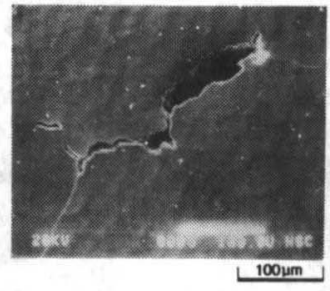

(a)

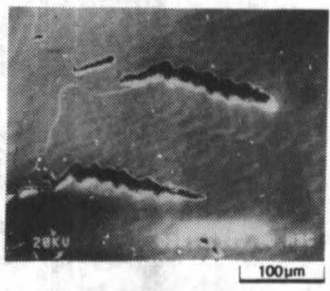

(b)
Fig. 3 Crackings in Ti-15V-3Al-3Cr-3Sn weld metal

(a) Cracking at $\beta$ grain boundaries

(b) Cracking at Cellular boundaries

\section{2 凝固割れ破面の解析}

Ti-15 V-3 Al-3 Cr-3 Sn 合金の割れ経路を Fig. 3 に 示す. 割れは, (a)のような粒界を進展しているあのあ観 察されるが, (b)のような粒内割れも多数観察される。さ らに,(b)の粒内割れでは, 凝固時のセル境界を進展して いるのが観察され，乙の現象は割れが発生した Ti-6 Al$6 \mathrm{~V}-2 \mathrm{Sn}$ 合金であ同様であった.

Fig. 4 は, Ti-15 V-3 Al-3 Cr-3 Sn 合金の割れ破面の 全景および各部の拡大破面を示したものである. 全体的 になめらかな起伏のある破面状態となっており, 高温側 A では, 極めて明瞭に频固時のデンドライトが観察され る.また, 低温側においてあデンドライト状の起伏か認 められ, さらに, 低温側において一部，C のようなテラ ス状の模樣が認められた。 これは, Weiss ら7) が報告し ている薄凰の液膜の存在を示唆する模样と類似してお り, 割れの最低温域においても非常に薄くはあるが, 液 膜が存在していたものと推察される。また, これらの傾 向は Ti-6 Al-6 V-2 Sn 合金の破面であ同様であり, 割 れ感受性と破面形態との間には明確な対応関係は諗めら れなかった。しかしながら，いずれの合金系の割れに 屯, 残留融液か関与しており, デンドライト境界での, この液膜の疑固終了温度が割れ感受性を支配する因子で あることが推察される。

\section{3 破面上の元素分布}

各合金溶接金属の凝固割れ破面部と溶接金属を室温で 引張試験して得られた延性破面部を AES 分析し, 各元 


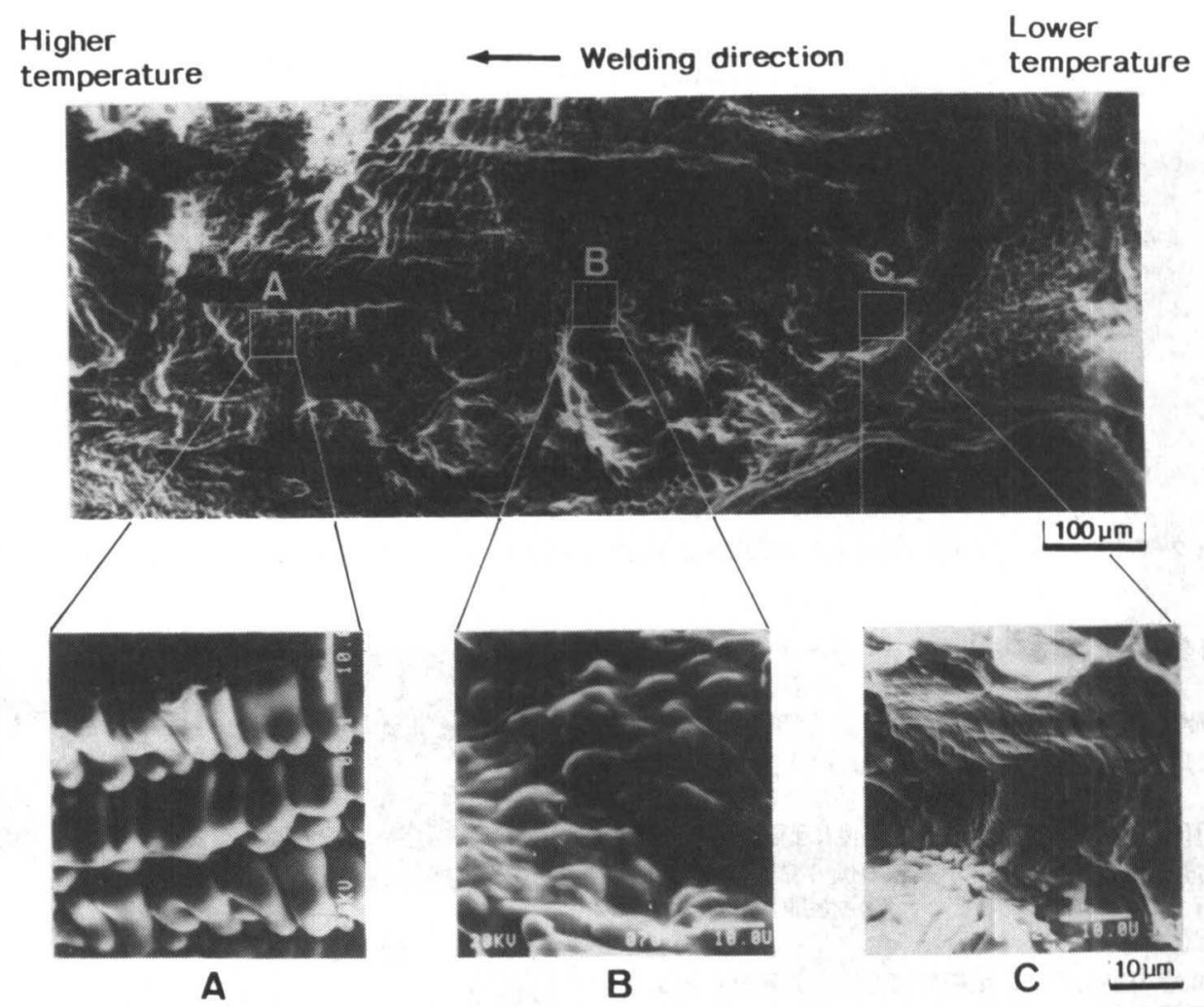

Fig. 4 SEM microfractographs of solidification crack in Ti-15V-3Al-3Cr-3Sn weld metal

Table 2 Element concentration on cracking and fractured surfaces obtained by AES spectra $\left(w t^{\circ}\right)$

\begin{tabular}{|c|l|c|c|c|c|c|}
\hline Alloy & \multicolumn{1}{|c|}{ Location } & $\mathrm{Al}$ & $\mathrm{V}$ & $\mathrm{Cr}$ & $\mathrm{Sn}$ & $\mathrm{Ti}$ \\
\hline \multirow{2}{*}{$\begin{array}{l}\text { Ti-6AI-6V- } \\
2 \mathrm{Sn}\end{array}$} & $\begin{array}{l}\text { Solidification } \\
\text { cracking surface }\end{array}$ & 8.80 & 6.71 & - & 0.08 & 84.41 \\
\cline { 2 - 7 } & $\begin{array}{l}\text { Ductile } \\
\text { fractured surface }\end{array}$ & 9.02 & 5.78 & - & 0.30 & 84.90 \\
\hline \multirow{2}{*}{$\begin{array}{l}\mathrm{Ti}-15 \mathrm{~V}-3 \mathrm{AI}- \\
3 \mathrm{Cr}-3 \mathrm{Sn}\end{array}$} & $\begin{array}{l}\text { Solidification } \\
\text { cracking surface }\end{array}$ & 4.52 & 20.33 & 3.69 & 2.35 & 69.11 \\
\cline { 2 - 7 } & $\begin{array}{l}\text { Ductile } \\
\text { fractured surface }\end{array}$ & 5.83 & 16.60 & 2.50 & 2.90 & 72.17 \\
\hline
\end{tabular}

素のピーク高さとその感度係数8) とから, 各元素の濃度 を計算した結果を Table 2 に示す, 両合金とも, 凝固割 れ破面部は，延性破面部より $\mathrm{V}$ および $\mathrm{Cr}$ が濃化して おり, 逆に $\mathrm{Al}, \mathrm{Sn}$ は減少している。特に, $\mathrm{Ti}-15 \mathrm{~V}-3$ Al-3 Cr-3 Sn 合金では V の濃化が著しくなっている. したがって，これらの元素の濃化がデンドライト境界で の凝固終了温度を低下させ, 割れが起こったものと推察 される。

\section{4 凝固偏析}

残留融液の凝固終了温度に影響を及ぼすと推察される 溶質元素の濃化について検討を加えるため, 各合金系の 凝固偏析挙動を調査した。

Fig. 5 は，スズ急冷法5)によって得られた三合金の溶 接凝固組織と各 A-A' 部を EPMA で測定した元素分配 を示したものである、 Ti-6 Al-4 V 合金では, 前報5) で 示した通り, デンドライト境界において $\mathrm{V}, \mathrm{Fe}$ が濃化 し, 逆に Al は若干減少している(a). また, Ti-6 Al-6 V-
2 Sn 合金では,デンドライト境界に V, Fe, Cu が濃化 し, Al, Sn は減少している(b).さらに, Ti-15 V-3 Al$3 \mathrm{Cr}-3 \mathrm{Sn}$ 合金では, デンドライト境界に $\mathrm{V}, \mathrm{Cr}, \mathrm{Fe}$ が濃化し, $\mathrm{Al}, \mathrm{Sn}$ は減少している(c).すなわち,てれら 三合金の疑固偏析をまとめると, 凝固時に, $\beta$ 安定元素 である $\mathrm{V}, \mathrm{Fe}, \mathrm{Cr}, \mathrm{Cu}$ を固相前面に排出し, 逆に, $\mathrm{Al}$, Sn はデンドライト内部に濃化して, 凝固が進行するこ とが明らかとなった。 とのととは Table 2 の AES 分析 結果と一致することが, $\mathrm{Fe}, \mathrm{Cu}$ については含有量が少 ないために AES では分析できなかったと考えられる.

さらに, 各合金の溶接凝固時の元素分布について CM A 分析した結果を Fig. 6,7,8 に示す. 図中において, 凝固は右から左側に進行しており, 左端が凝固界面先端 である.また, CMA 分析において白色部ほど元素が濃 化し，黒色部ほど元素が久乏していることを示してい る.三合金とも凝固界面先端において, 各元素の偏析が 著しい領域が認められる。この領域は固液共存領域で あって，凝固中における溶質元素の固液間の分配をかな り正確に表わしていると考えられる。そこで，これらの CMA 結果から求められる固液共存領域のデンドライト 境界における固液界面での固相中の濃度と液相中の濃 度との比から計算した平衡分配係数を Table 3 に示す. Table 3 から明らかなように, おのおのの溶質元素につ いては, 合金系の違いによる平衡分配係数の変化は少な いが, $\mathrm{Fe}, \mathrm{Cu}, \mathrm{Cr}$ のそれは1よりかなり小さい值と なっていることが明らかとなった。したがって, デンド ライト境界では $\mathrm{Fe}, \mathrm{Cu}, \mathrm{Cr}$ の龊固時の濃化が大きく， 

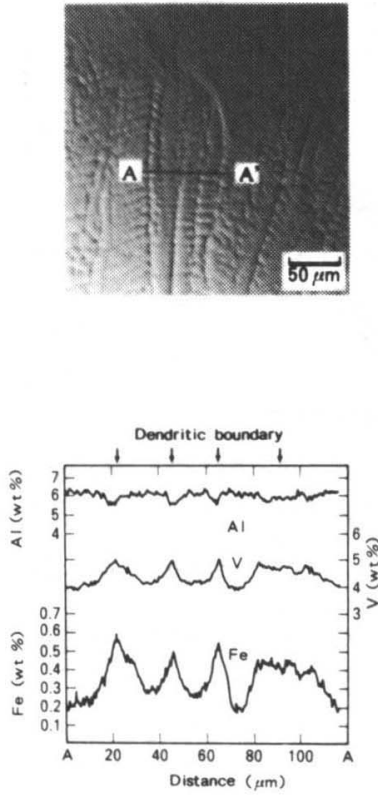

(a)

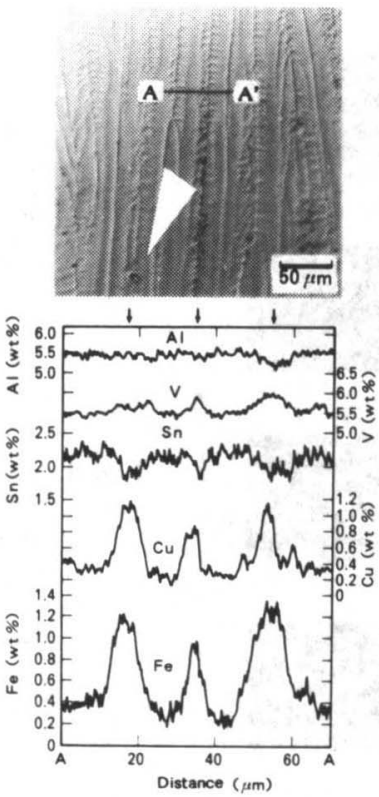

(b)
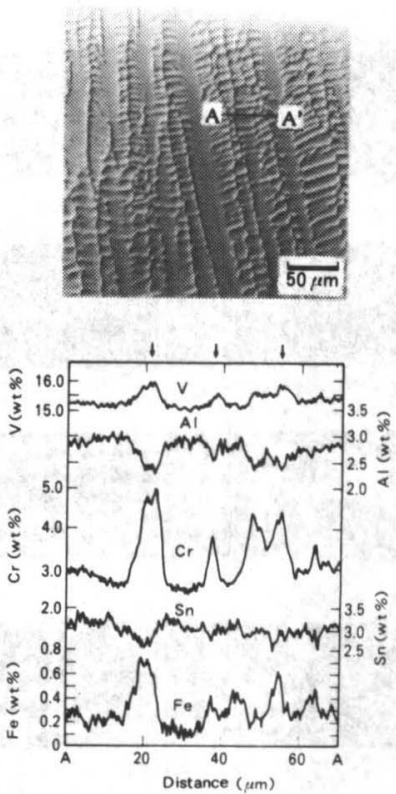

(c)

Fig. 5 Solidification microstructures and element distributions in the weld metals
(a) Ti-6Al-4V
(b) Ti-6Al-6V-2Sn
(c) Ti-15V-3Al-3Cr-3Sn

Solidification front

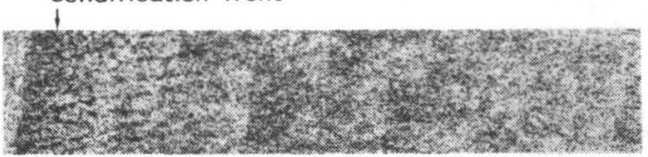

(a) Al

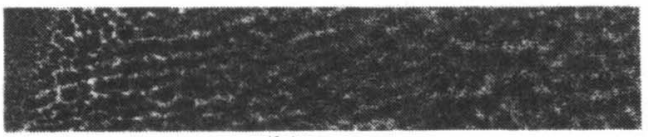

(b) $\mathrm{V}$

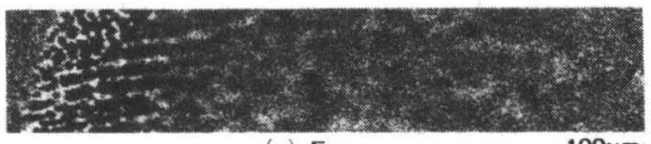

(c) $\mathrm{Fe}$

$100 \mu \mathrm{m}$

Fig. 6 Microsegregation during solidification in the weld metal of Ti-6Al-4V
(a) $\mathrm{Al}$ (b) $\mathrm{V} \quad$ (c) $\mathrm{Fe}$

これが凝固割れの原因であると推察される。

さらに, Fig. 6, 7,8 に示すように, Ti-6 Al-4 V 合金 は, 凝固界面先端から約 $100 \mu \mathrm{m}$ 以上右側の領域では, 各溶質元素とも凝固偏析は消堿し, ほほ均一に分布して いるのに対し, Ti-6 Al-6 V-2 Sn, Ti-15 V-3 Al-3 Cr-3 Sn 合金では, 測定した全域に偏析が残り, かなりの低 温部まで均一化されないことが観祭される。そこで, 三 合金と屯に含まれる Fe に注目して, 凝固偏析の凝固後 冷却過程におりる変化を示したのが Fig. 9 である。横軸 は凝固界面先端からの距離, 縦軸はバルクの $\mathrm{Fe}$ 濃度 $\left(\mathrm{C}_{0}\right)$ に対するデンドライト境界での $\mathrm{Fe}$ 濃度 $\left(\mathrm{C}_{d b}\right)$ の

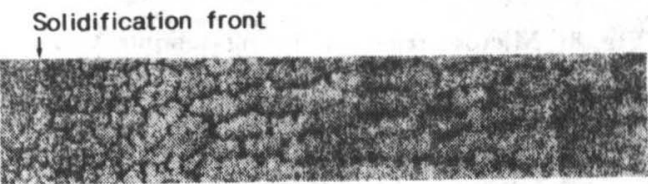

(a) Al

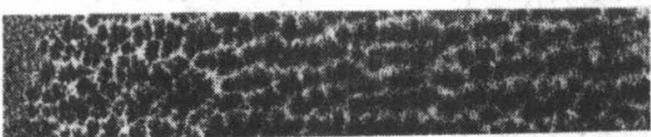

(b) $\mathbf{V}$

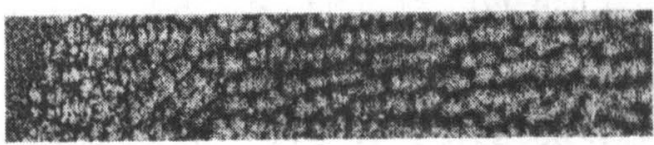

(c) $\mathrm{Sn}$

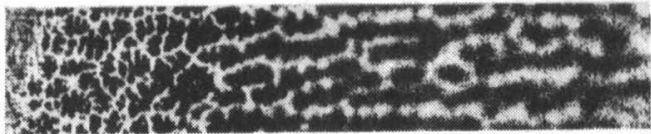

(d) $\mathrm{Fe}$

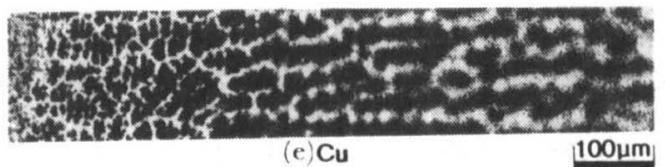

Fig. 7 Microsegregation during solidification in the weld metal of Ti-6Al-6V-2Sn
(a) $\mathrm{Al}$
(b) $\mathrm{V} \quad$ (c) $\mathrm{Sn} \quad$ (d) $\mathrm{Fe}$
(e) $\mathrm{Cu}$ 
Solidification front

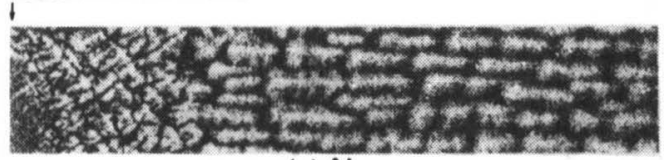

(a) Al

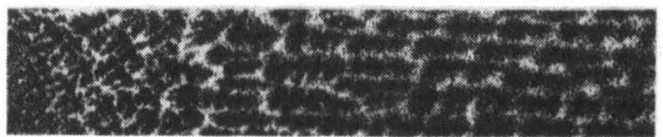

(b) $\mathrm{V}$

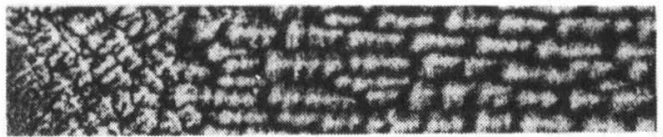

(c) $\mathrm{Sn}$

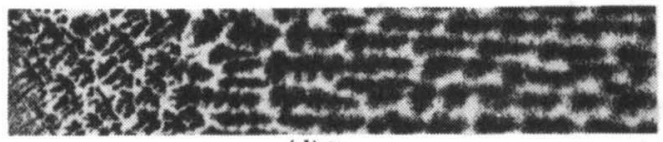

(d) $\mathrm{Cr}$

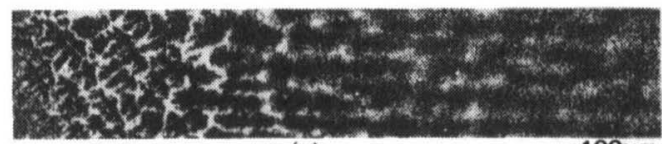

(e) $\mathrm{Fe}$

$100 \mu \mathrm{m}$

Fig. 8 Microsegregation during solidification in the weld metal of Ti-15V-3Al-3Cr-3Sn
(a) $\mathrm{Al}$
(b) $\mathrm{V}$
(c) $\mathrm{Sn}$
(d) $\mathrm{Cr}$ (e) $\mathrm{Fe}$

Table 3 Equilibrium distribution coefficient of solute elements in Ti-alloys

\begin{tabular}{|l|c|c|c|c|c|c|}
\hline \multicolumn{1}{|c|}{ Alloy } & Al & V & $\mathrm{Fe}$ & $\mathrm{Sn}$ & $\mathrm{Cu}$ & $\mathrm{Cr}$ \\
\hline $\mathrm{Ti}-6 \mathrm{Al}-4 \mathrm{~V}$ & 1.02 & 0.89 & 0.65 & - & - & - \\
\hline $\mathrm{Ti}-6 \mathrm{~A} 1-6 \mathrm{~V}-2 \mathrm{Sn}$ & 1.02 & 0.91 & 0.61 & 1.09 & 0.52 & - \\
\hline $\mathrm{Ti}-15 \mathrm{~V}-3 \mathrm{~A} 1-3 \mathrm{Cr}-3 \mathrm{Sn}$ & 1.08 & 0.95 & 0.71 & 1.13 & - & 0.79 \\
\hline
\end{tabular}

比 $\left(\mathrm{C}_{d b} / \mathrm{C}_{0}\right)$ を示している。.三合金とあ, 凝固界面先端 から内部に入るにつれ, すなわち, 冷却されるにつれ, デンドライト境界での $\mathrm{Fe}$ 濃度は減少しているが, 特に Ti-6 Al-4 V 合金では, 凝固界面先端からの距離が 300 ４00 $\mu \mathrm{m}$ で，ほぼバルク組成に均一化されており，凝 固偏析は極めて速く消滅している。一方, Ti-6 Al-6 V$2 \mathrm{Sn}, \mathrm{Ti}-15 \mathrm{~V}-3 \mathrm{Al}-3 \mathrm{Cr}-3 \mathrm{Sn}$ 合金では, デンドライト 境界の $\mathrm{Fe}$ 濃度の減少の程度は小さく, 凝固偏析はほと んど消滅していない。さらに, Ti-15 V-3 Al-3 Cr-3 Sn 合金の方が，バルクの $\mathrm{Fe}$ 濃度に対するデンドライト境 界での $\mathrm{Fe}$ の濃度比は大きく, 凝固界面先端から 400 $\mu \mathrm{m}$ 内部に入った所であバルク濃度の二倍以上残存して いるととが判明した。 なお，この傾向は他の溶質元素に ついてあ同様であった。

\section{$3.5 \mathrm{Fe}$ の拡散挙動}

合金系による疑固偏析の均一化の違いは，各合金中に

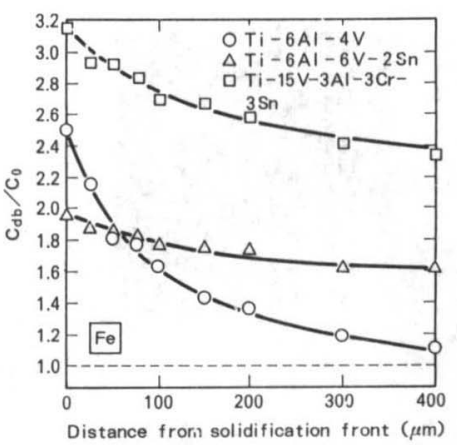

Fig. 9 Relation between $\mathrm{Fe}$ concentration at dendritic boundary and distance from solidification front

$\mathrm{C}_{\mathrm{db}}$ : $\mathrm{Fe}$ concentration at dendritic boundary

$\mathrm{C}_{\mathrm{o}}$ : nominal composition

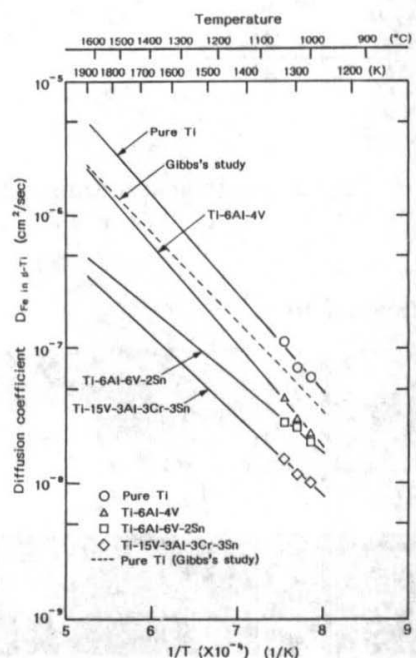

Fig. 10 Diffusion coefficient of $\mathrm{Fe}$ in Ti-alloys

おける拡散速度が異なっているためと考えられる．そこ で，すべての合金に含まれている Fe の拡散挙動につい て検討を行なった。 $\beta$ - Ti 中の $\mathrm{Fe}$ の拡散は, $\mathrm{Ti}$ の自己 拡散より十分速く9)，また， Ti 合金とステンレス鎆との 拡散接合において拡散は一次元方向にのみ起こり, ステ ンレス鋼側から Ti 合金側へは常に十分な Fe が供給さ れると仮定すると, 等温保持中の拡散方程式は次式のよ うに書ける。

$\partial \mathrm{C}(x, t) / \partial t=D \partial^{2} C(x, t) / \partial x^{2}$ 初期条件

$$
\begin{aligned}
& C(x, 0)=C_{1} \quad(x<0) \\
& C(x, 0)=C_{0} \quad(x>0)
\end{aligned}
$$

境界条件

$$
C(0, t)=C_{1}
$$

ただし， $C, t, x$ は濃度, 接合時間, 接合界面からの $\mathrm{Ti}$ 合金側での距離, $C_{0}, C_{1}$ は $\mathrm{Ti}$ 合金およびステンレス 鋼のバルク濃度であり, $D$ は固相内の拡散係数である. これらの条件をあとに(1)式を解くと(5)式が得られる. 


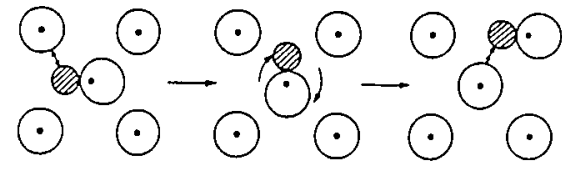

(a)

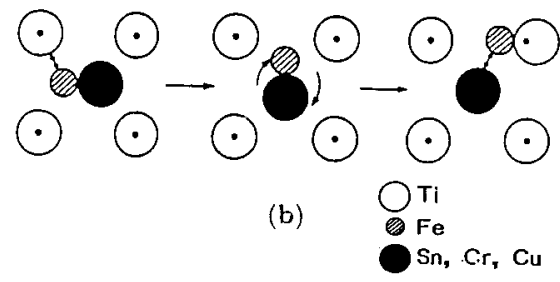

Fig. 11 Models of diffusion of $\mathrm{Fe}$ in Ti-alloys

(a) in pure $\mathrm{Tj}$ and $\mathrm{Ti}-6 \mathrm{Al}-4 \mathrm{~V}$

(b) in Ti-6Al-6V-2Sn and Ti-15V$3 \mathrm{Al}-3 \mathrm{Cr}-3 \mathrm{Sn}$

$$
\begin{aligned}
\left(C(x, t)-C_{0}\right) /\left(C_{1}-C_{0}\right) \\
=1-\operatorname{erf}\left(x^{\prime} \cdot 2 \cdot(D t)^{1 / 2}\right)
\end{aligned}
$$

ただし, erf (z) は愦差関数である。

ここで，昖散接合後の $\mathrm{Ti}$ 合金中における接合界面に 直角方向の $\mathrm{Fe}$ の濃度分布を測定し, (5)式に代入するこ とにより $\mathrm{Fe}$ の㹡散係数を計算した，Fig. 10 に各 $\mathrm{Ti}$ 合 金中での Fe の挔散係数を示す. なお, 図中の破線は Gibbs が求めた純 $\mathrm{Ti}$ 中での Fe の拡散係数10)である。と ころで， Ti-Fe 系においては $1358 \mathrm{~K}$ で共晶が晶出し， それ以上の温度では拡散接合が不可能のため，1323 K 以下で $\beta$ 坚相域の三温度で实験を行ない，高温域での 搪散係数は外挿で求めた. Fig. 10 より明らかなように， Ti-6 Al-4 V 合金中での Fe の抬散係数は純 Ti 中での それとほぼ近似しており，また，Gibbs の結果とも良く 刘応している。一方, Ti-6 Al-6 V-2 Sn, Ti-15 V-3 Al-3 Cr-3 Sn 合金中では, 高温域において拡散係数が純 $\mathbf{T i}$ 中および Ti-6 Al-4V 合金中のそれより 1 オーダー小 さいととが明らかよなった，したがって，Ti-6 Al-6 V$2 \mathrm{Sn}, \mathrm{Ti}-15 \mathrm{~V}-3 \mathrm{Al}-3 \mathrm{Cr}-3 \mathrm{Sn}$ 合金では, 凝固偏析の均 一化が逮くなると考えられる。とてろで，とのように合 金系により Fe の拡散速度に違いが現れる原因としては 次のように考えられる.すなわち， $\beta$-Ti 中の Fe の抬散 は一般には Fig.11(a)"1) に示すような Fe 原子が侵入型 原子位置に配置される解離桩散 ${ }^{12}$ であるため，高速拡散 すると言われている。しかしながら，乙れに Sn，Cr， $\mathrm{Cu}$ 等が添加されると，Fig. 11(b) のように Fe とこれら の原子が結合して微小な化合物を生成するため， Fe の 拡散が遅くなったと考えられる*)。

ところで，上述のように合金系により桩散速度に違い があることから，次に，凝固偏析に及ぼす凝固中の固相 㧓散の影響を各合金について検討を行なった。なおて の場合も偏析量が多く，三合金すべてに含まれる Fe に ついて検討を行なった。元素の拡散を考虑に入れた固液 界面の固相中での溶質濃度は Scheil の式 ${ }^{14)}$ を変形して 次式15)で表わせる。

$$
\begin{aligned}
& C_{s}=K C_{0}\left(1-f_{s} /(1+\alpha K)\right)^{K-1} \\
& \alpha=4 D_{s} t_{f} / d^{2}
\end{aligned}
$$

\begin{tabular}{|c|c|c|c|}
\hline & $T i-6 A l-4 V$ & $\begin{array}{l}T i-6 A I-6 V- \\
2 S n\end{array}$ & $\begin{array}{l}T j-15 V-3 A 1 \\
-3 \mathrm{Cr}-3 \mathrm{Sn}\end{array}$ \\
\hline 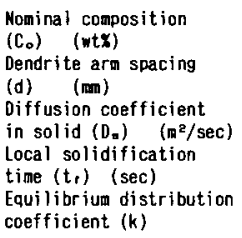 & $\begin{array}{c}0.22 \\
2 \times 10^{-2} \\
2.5 \times 10^{-10} \\
0.06 \\
0.65\end{array}$ & $\begin{array}{l}0.75 \\
2 \times 10^{-2} \\
4.9 \times 10^{-11} \\
0.12 \\
0.61\end{array}$ & $\begin{array}{c}0.21 \\
2 \times 10^{-2} \\
3.5 \times 10^{-11} \\
0.10\end{array}$ \\
\hline
\end{tabular}

* 同様の現象がPb-Cd中のNiの昖散 ${ }^{13)}$ て発生している
Table 4 Constants used for calculation of solidification segregation

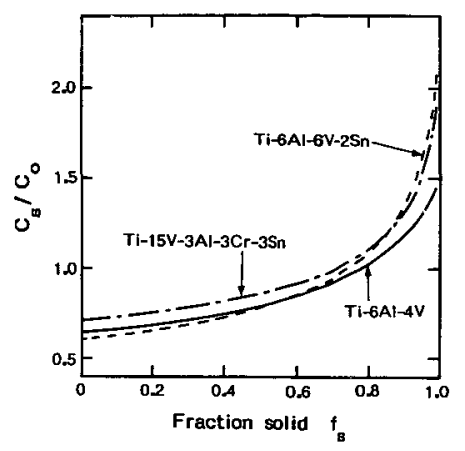

Fig. 12 Effect of solid diffusion during solidification on solidification microsegregation

ただし， $f_{s}$ : 固相率， $C_{s}$ : 固相率 $f_{s}$ の時の固液界面の 固相中の溶質濃度， $K$ : 平衡分配係数， $C_{0}$ : バルク濃 度, $D_{s}$ : 固相中の㹡散係数, $t_{f}$ : 同部凝固時間, $d:$ 一 次アームスペーシングである。乙とで各合金の固液界面 における固相中の $\mathrm{Fe}$ の偏析量 $\left(C_{s} / C_{0}\right)$ を Table 4 亿 示した定数を用いて計算した結果が Fig. 12 である。な お, Table 4 において $d$, $t_{f}$ は Fig.6,7,8 の CMA 結 果および溶接速度から換算したあのであり， $D_{s}$ は Fig. 10 から求めたものである. Fig.12 から明らかなように， Ti-6 Al-6 V-2 Sn, Ti-15 V-3 Al-3 Cr-3 Sn 合金の最終 疑固部におりる $\mathrm{Fe}$ の偏析量は，平衡分配係数がほとん 亡゙同じの Ti-6 Al-4 V 合金に比べ大きくなっている。し たがって，Ti-6 Al-6 V-2 Sn, Ti-15 V-3 Al-3 Cr-3 Sn 合金では， $\mathrm{Fe}$ の拉散速度が小さいため，漏析に及住す 凝固中の固相㹡散の影響は，Ti-6 Al-4 V 合金に比べ少 ないととが判明した．また，Fe 以外の溶筫元素につい ても3.4項で述べたように Ti-6 Al-6 V-2 Sn, Ti-15 V$3 \mathrm{Al}-3 \mathrm{Cr}-3 \mathrm{Sn}$ 合金では凝固偏析の均一化が遅いため, 掋散速度は小さいと推祭され，凝固中の固相拡散の影牟 は少ないと考えられる。

\section{6 溶接疑固割れ譏構}

Ti-6 Al-4 V 合金では溶接凝固時のデンドライト境界 に V, Fe が濃化するが，㹡散速度が大きいために，乙 れらの凝固偏析は凝固終了後, 梗めて早い段階で消减す る.したがって，デンドライト境界での残留融液の凝固 終了温度が系全体の固相線温度とほとんど同じために， 凝固割れは発生しないと考えられる，一方，Ti-6 AI-6 V $-2 \mathrm{Sn}, \mathrm{Ti}-15 \mathrm{~V}-3 \mathrm{Al}-3 \mathrm{Cr}-3 \mathrm{Sn}$ 合金では，溶接凝固時 
のデンドライト境界に V， Fe，Cu， Cr が湿化するが， 特に $\mathrm{Fe}, \mathrm{Cu}, \mathrm{Cr}$ の平衡分配係数は小さいため，それら の濃化の程度は極めて大きい，さらに，凝固中の固相抬 散の影響が少ないため, 特に, 凝固最終部での Fe の偏 析量は Ti-6 Al-4V 合金に比べて, 平衡分配係数がほと んど同じにもかかわらず，大きくなる．また，溶質元素 の拡散速度が小さいため，乙れらの凝固偏析の消隇は遅 く，デンドライト境界に $\mathrm{Fe}, \mathrm{Cu}, \mathrm{Cr}$ 濃度の高い融液が 低温まで残り，乙の残留融液の凝固終了温度が系全体の 固相線温度より大幅に低下し，凝固割れが発生したあの と考えられる。

\section{4. 結 論}

各種 $\mathrm{Ti}$ 合金の溶接凝固割れについて検討した結果， 以下のととが判明した。

(1) トランスーバレストレイン試験の 結果, Ti-6 Al-4 $\mathrm{V}$ 合金では疑固割れは全く起こらず，耐凝固割れ性が極 めて優れている。一方, Ti-6 Al-6 V-2 Sn, Ti-15 V-3 Al-3 Cr-3 Sn 合金では， 0.5\%を越える付加ひずみ量で 疑固割れが発生する。 また， Ti-15 V-3 Al-3 Cr-3 Sn 合 金の方が Ti-6 Al-6 V-2 Sn 合金より割れ感受性は高い.

(2) 凝固割れの破面形態は，凝固時のデンドライトが 明暸に観察され，凝固割わには牫留融液が関与している ことが判明した。また，凝固割れ破面上を AES 分析し た結果，V， Cr が濃縮していた。

(3) 各合金亡も溶接凝固時にはデンドライト境界に $\beta$ 安定元素 $(\mathrm{V}, \mathrm{Fe}, \mathrm{Cr}, \mathrm{Cu})$ が濃化し， Al, Sn は減少 している. 特に, $\mathrm{Fe}, \mathrm{Cr}, \mathrm{Cu}$ の平衡分配係数は 1 より かなり小さく，濃化の程度は大さい。

(4) Ti-6 Al-4 V 合金では，溶質元素の拡散速度が大 きいため, 凝固倔析は極めて速く消隇し，早い段階で均 一に分布する。一方, Ti-6 Al-6 V-2 Sn, Ti-15 V-3 Al$3 \mathrm{Cr}-3 \mathrm{Sn}$ 合金では，溶質元素の搪散速度が小さいため， 凝固中の固相拡散の影響は小さく，さらに，乙れらの凝 固偏析は均一化が遅く，低温まで残る。

(4) Ti-6 Al-6 V-2 Sn, Ti-15 V-3 Al-3 Cr-3 Sn 合金 の凝固割れの発生機構については， $\mathrm{Fe}, \mathrm{Cu}, \mathrm{Cr}$ の平衡 分配係数が 1 よりかなり小さく, さらに凝固中の固相拡 散の影響が少ないために，溶接凝固時のデンドライト境
界での濃化の程度は極めて大きくなる。またててれらの 凝固偏析の消城は遅く，デンドライト境界に高濃度の殷 液が低温まで残るために，乙の残留融液の凝固終了温度 が系全体の固相線温度より大幅に低下し，凝固割れが発 生すると考えられる.

\section{参考 文 献}

1) W. A. Baeslack III: Observations of Solidification Cracking in Ti Alloy Weldments, Metallography, 13 (1980), 277

2) D. Hayduk, B. K. Damkroger, G. R. Edwards and D. L. Olson: Cracking Susceptibility of Ti-6 Al-2 Nb-1 Ta-0.8 Mo as Determined by the Varestraint Test, Weld. J., 65 (1986), $251 \mathrm{~S}$

3) W. F. Savage, et al:: The Evaluation of Weldability of Structural Alloys with the Varestraint Test, AFML - TR$68-48$ (1968)

4) W. A. Baeslack III, D. W. Becker and F. H. Froes: Advances in Titanium Alloy Welding Metallurgy, Journal of Metals, 36 May (1984), 46

5) 井上, 小川I： $\mathrm{Ti}-6 \mathrm{Al}-4 \mathrm{~V}$ 合金の溶接金属組織に及黑方冷却 速度及び不純ガスの影響, 溶接学会論文集, 9 (1991), 129

6) 中尾，策崎，路：Ni基超耐熱合金の高温割れに関する研究，第 105回溶接冶金研究委員会資料，WM-1130-86 (1986)

7) B. Weiss, et al; Physical Metallurgy of Hot Ductility Testing, Weld. J., 49 (1970) $471 \mathrm{~S}$

8) HANDBOOK OF AUGER ELECTRON SPECTROSCOPY, (P. E. D.), 4

9) 金属データブック，日本金属学会編 (丸善)，28

10) G. B. Gibbs, D. Graham and D. H. Tomlin: Diffusion in Titanium-Niobium Alloys, The Philosophical Magazine, 8(1963), 1269

11) W. K. Warburton and D. Turnbull: Diffusion in Solid, Academic Press, (1975), 171

12）中鴄：鉛など2，3の金属中での不純物の高速拡散，日本金属学 会会報, 22 (1983), 480

13) H. Nakajima: Diffusion of Nickel in Lead-Cadmium Alloys, Scripta Metallurgica, 15 (1981), 577

14) E. Scheil: Bemerkungen zur Schichtkristallbildung, Zeitschrift fur Met Likunde, 34 (1942), 70

15) M. C. Flemings: Solidification Processing (McGraw-Hill), (1974) 145 